\title{
Contribution of parental attachment and involvement to the academic, emotional and social adjustment to college: A three-year longitudinal study
}

\author{
Sanja Smojver-Ažić, Tamara Martinac Dorčić and Jasminka Juretić \\ Department of psychology, Faculty of Humanities and Social Sciences, University of Rijeka, Croatia
}

\begin{abstract}
This three-year longitudinal study explored the effects of parental attachment and initial college adjustment on students' perception of parental involvement in academic functioning as well as contributions of several parenting dimensions to academic, emotional and social adjustments after three years of college. A total of 171 Croatian college students (118 females) completed questionnaires related to their parental attachment, parental involvement in academic functioning, and adjustment to college. Data were analyzed by hierarchical regression analysis. Results suggested that parental involvement in academic functioning in the second year is more related to the quality of attachment to parents than to the initial adjustment to college. While attachment was a significant predictor of only emotional adjustment, parental support in academic functioning predicted academic and social adjustment to college after three years of college. Results suggest that various factors related to parenting continue to play an important role in different aspects of students' adjustment to college.
\end{abstract}

Keywords: adjustment to college, attachment to parents, parental involvement, longitudinal studies

\section{Prispevek navezanosti na starše in vključenosti staršev $k$ akademskemu, čustvenemu in socialnemu prilagajanju na študij: tri-letna vzdolžna raziskava}

\author{
Sanja Smojver-Ažić, Tamara Martinac Dorčić in Jasminka Juretić \\ Oddelek za psihologijo, Fakulteta za humanistične in družbene vede, Univerza v Reki, Hrvaška
}

Povzetek: V tri-letni vzdolžni raziskavi smo preučevali učinke navezanosti na starše in začetne prilagoditve na študij na zaznave študentov glede vključenosti staršev v njihovo akademsko delo. Poleg tega smo obravnavali prispevek večjega števila starševskih dimenzij na akademsko, čustveno in socialno prilagajanje študentov po treh letih študija. Na vzorcu 171 hrvaških študentov smo aplicirali vprašalnike glede navezanosti na starše, vključenosti staršev v njihovo akademsko funkcioniranje in prilagajanja na študij. Rezultati hierarhičnih regresijskih analiz so pokazali, da je vključenost staršev v akademsko delo študentov $\mathrm{v}$ drugem letniku študija $\mathrm{v}$ večji meri povezano $\mathrm{s}$ kakovostjo navezanosti na starše kot $\mathrm{z}$ začetno prilagoditvijo na študij. Medtem ko je navezanost na starše statistično značilno napovedovala le čustveno prilagoditev, je podpora s strani staršev pomembno napovedovala akademsko in socialno prilagoditev po treh letih študija. Rezultati nakazujejo, da imajo različni dejavniki, vezani na starše, tudi v času študija še vedno pomembno vlogo pri različnih vidikih prilagajanja študentov na študij.

Ključne besede: prilagoditev na študij, navezanost na starše, vključenost staršev, longitudinalne študije

\footnotetext{
*Naslov/Address: dr. Sanja Smojver-Ažić, Department of psychology, Faculty of Humanities and Social Sciences, University of Rijeka, Sveučilišna avenija 4, 51000 Rijeka, Croatia, e-mail: smojver@ffri.hr 
Attending university presents students with many challenging experiences related to new demands that extend academic functioning, and requires multiple adaptations. According to the theoretical taxonomy of Baker and Siryk (1984), college adjustment as a multidimensional construct postulates academic, personal-emotional and social adjustment and institutional attachment. While adjustment to college can be considered a predictor of academic performance and college retention, it can also be viewed as an important outcome related to a wide array of factors (Gerdes \& Mallinckrodt, 1994; Mattanah, Hancock, \& Brand, 2004). In their meta-analytic review of the adjustment to college, Crede and Niehorster (2012) presented results for different antecedents and correlates of adjustment, one of them being the relationship with parents. The present study is a longitudinal investigation of various factors related to parenting as predictors of college student adjustment.

Although studies have demonstrated that parents can positively influence adjustment across different educational settings, i.e. kindergarten, elementary, middle or high school (Hill \& Tyson, 2009), the relationship with parents was not always adequately stressed as a determinant of adjustment to college (Agliata \& Renk, 2008; Fan \& Chen, 2001; Taub, 2008). Usually it was acknowledged as a source of influence on students' pre-college experiences (represented by measures of parental education, income or occupation) or through the process of "leaving home" during the transition to college but not as parental involvement during college years (Sax \& Wartman, 2010). This is probably the result of assumptions that parental involvement should decline during late adolescence due to adolescents' greater need for autonomy (Allen, Hauser, Bell, \& O’Connor, 1994; Rice, 1992).

The changes in parent-child relations are necessary and related to the children's needs during development (Karavasilis, Doyle, \& Markiewicz, 2003; Soenens \& Vansteenkiste, 2005). As the majority of college students is in the period of emerging adulthood (Arnett, 2004) and strives to become independent and self-reliant, the parentchild dyad enters a new stage. Emerging adulthood is described by relative independence from social roles and normative expectations, identity exploration, instability, self-focus and feelings of being "in between". Due to the specificity of this developmental period, the parent-child relationship is different but may still be relevant in helping their children navigate this period of exploration (Agliata \& Renk, 2008; Nelson, Padilla-Walker, Christensen, Evans, \& Carroll, 2011; Wintre \& Yaffe, 2000). The nature of this relation depends on living arrangements or economic support and may be culturally specific (Zupančič, Komidar, \& Puklek Levpušček, 2014).

The parent-student relation can be analyzed through several theoretical frameworks that stress different aspects of this relation: e.g. the process of separation-individuation, attachment or satisfaction of developmental needs. According to the theory of separation-individuation, during the transition to college, acquiring autonomy and individuation are considered to be necessary developmental goals (Sax \& Wartman, 2010). Students have to learn to function with emotional independence and without the need for approval from their parents (Chickering \& Reisser, 1993). The framework of attachment emphasizes the life-long importance of close relationships and it challenges the concept of separationindividuation. The college environment represents a novel situation that may activate the attachment system, especially for students who live away from their parents (Kenny, 1987; Rice, FitzGerald, Whaley, \& Gibbs, 1995; Wei, Russell, \& Zakalik, 2005). Secure attachment relationships offer support in times of stress, allowing students to better adjust during the process of leaving home and acclimatizing to a new academic environment (Bernier, Larose, Boivin, \& Soucy, 2004; Kenny, 1987; Lapsley, Rice, \& FitzGerald, 1990). Mattanah, Lopez, \& Govern (2011) reported findings from a meta-analysis of 156 studies that examined the relationship between selfreported parental attachment and multiple adjustment outcomes during the college years. They found a smallto-medium relationship between indicators of parental attachment quality and favorable adjustment outcomes. According to Bernier et al. (2004), preoccupation with attachment is related to poor adjustment in college during the freshman year. Insecurely attached students reported greater depression, anxiety and worry than securely attached (Vivona, 2000). Mattanah et al. (2004) and Schultheiss and Blustein (1994) stressed that it may be a combination of separation-individuation and secure attachment that leads to positive adjustment. Students with secure attachment feel more comfortable about the process of separation-individuation and are better adjusted to college.

The process of gaining autonomy and the importance of a close relationship is further elaborated in the selfdetermination theory that stresses lifelong needs for autonomy, competence and relatedness (Grolnick, Deci, \& Ryan, 1997). The satisfaction of these needs predicts adaptive patterns of cognitions, behaviors and emotions (Ryan\&Deci, 2000). Satisfaction of students' psychological needs in the university context may be related to two aspects of parenting: parental involvement and support of autonomy (Ratelle, Larose, Guay, \& Senécal, 2005). The construct of parental involvement implies the engagement of parents in their children's lives by providing emotional, cognitive and material resources to the child (Grolnick et al., 1997). More involved parents provide emotional resources (e.g., warmth and availability) that are necessary for their children to develop feelings of self-determination and confidence in their own abilities (Grolnick \& Ryan, 1989). The degree and manner of a parent's involvement in their child's life varies as a function of a certain domain of the lives of the children (Grolnick et al., 1997; Soenens \& Vansteenkiste, 2005). In college students, parental involvement reflects a more general trend of parents showing interest in the lives of their offspring and in gaining more information about college (Wartman \& Savage, 2008). It usually benefits student learning and achievement (Soucy \& Larose, 2000). Parental support of 
autonomy refers to the affirmation of the child as a unique, active and volitional being, expressed by acknowledging the child's perspective and independent thinking and by providing opportunities to make choices. This support of autonomy predicts self-regulation, competence and achievement. Different theoretical explanations about the role of parents in students' adjustment have resulted in various operationalizations of parent-student relations during college (Vivona, 2000).

Sax and Wartman (2010) stressed in their review that there still remains the question about the effect of various forms of parental involvement on student development over the course of the student's college career. In analyzing the role of parents, it will be useful to integrate several theoretical concepts and consider possible complementary roles of different aspects of parent-student relationships. Furthermore, as most studies on the relationship between parents and student adjustment have been cross-sectional, it is difficult to consider parental involvement or parentstudent relations as a predictor of student development. Studies using longitudinal pretest-posttest designs that suggest causality are rare (Gerdes \& Mallinckrodt, 1994; Rice et al., 1995; Wei et al., 2005).

Considering all mentioned findings and theoretical interpretations, the present longitudinal study was designed to explore more closely the role of parenting in college student adjustment. First aim was to analyze predictive effects of attachment to parents and initial adjustment to college on students' perception of parental involvement in academic functioning. Our hypothesis is that parental involvement in academic functioning in the second year correlates higher with the quality of attachment to parents than with the initial adjustment to college. Second aim was to analyze the contribution of different parenting dimensions (attachment and involvement in academic functioning) to the academic, emotional and social adjustment of students after three college years. We hypothesized that student relation with parents through attachment as a distal and parental involvement as a proximal factor should be related to multiple indicators of college student adjustment.

\section{Method}

\section{Participants}

An initial sample of 478 students (281 females) randomly selected from the University of Rijeka, Croatia, participated in the first phase of this 3-year longitudinal study. A sample was representative for University of Rijeka: participants were selected using a method of random numbers according to the official list of first-year students. The final number of students (participating in all three phases) was 171 (118 female), which represents $35.7 \%$ of initial sample. Student age in the first year of study ranged from 18 to 29 years $(M=19.02, S D=1.14$ years). Forty-five percent of the participants lived with their parents, while the remaining students lived alone or with relatives, friends or partners. The pattern of demographic variables related to gender, age and residential status of students in our sample is common for Croatian students (Farnell, Doolan, Matković, \& Cvitan, 2011).

Students who participated in all three phases were compared to those who participated only in the first phase regarding variables measured in the first phase (attachment and adaptation to college). $T$-tests showed that these two groups of students differed statistically significantly only in academic adjustment which was lower for students who participated only in the first phase. According to the data from the student service office, $72.5 \%$ students who participated in all phases of this study completed their study on time compared to $31.7 \%$ of students who participated only in the first phase.

\section{Measures}

Demographics. The participants reported on their age, gender, faculty, college year, and residential status. Residential status refers to the possible change in their place of residence due to their college attendance (i.e. if they live with or away from parents when attending college classes).

Attachment to parents. Attachment was measured using a modified Experiences in Close Relationship Inventory (Brennan, Clark, \& Shaver, 1998) that was shortened and adapted for a Croatian sample, while maintaining the psychometric characteristics of the original instruments (Kamenov \& Jelić, 2003; Kamenov \& Jelić, 2005). According to the authors, this modified scale may be used not only for measurement of attachment to a romantic partner but also for attachment to a family member and friends. This shortened version of the questionnaire consists of 18 items, each rated on a scale from (0) I do not agree to (7) I fully agree to assess the extent to which the item corresponds to the person's general feelings towards his mother and father. The questionnaire has two subscales: avoidance (9 items) and anxiety (9 items) with good reliability: for avoidance subscale $\alpha=.94$, and for anxiety subscale $\alpha=.91$ (Kamenov \& Jelić, 2005). Obtained Cronbach alpha coefficients, computed on the present sample, are also satisfactory (for avoidance $\alpha=.83$ for mothers and fathers; for anxiety $\alpha$ $=.71$ for mothers and $\alpha=.69$ for fathers). Because of a high correlation between the corresponding dimensions of attachment to mother and father (for avoidance $r=.71$, for anxiety $r=.89$ ), combined scores for mothers and fathers on both dimensions were calculated. The anxiety dimension refers to the fear of rejection or abandonment (sample items: I worry about being abandoned; I worry that she/he won't care about me as much as I care about her/him), whereas avoidance reflects the experience of discomfort caused by closeness and dependency on others (sample items: I feel comfortable sharing my private thoughts and feelings with her/him (reverse coded); I am nervous when she/he gets too close to me). Higher scores indicate more anxiety or avoidance. Correlation between avoidance and anxiety was $r=.18, p<.01$. High 
level on either dimension alone or both dimensions in combination means insecure attachment orientation, while low levels of both dimensions is typical for secure attachment (Kamenov \& Jelić, 2005). Two-dimensional factor structure, high reliability and predictive validity of versions of Experiences in Close Relationship Inventory are well documented in different studies (e.g. Hanak \& Dimitrijevic, 2013; Kamenov \& Jelić, 2005; Wei, Russell, Mallinckrodt, \& Vogel, 2007).

Parental involvement in academic functioning. Parental involvement in academic functioning was measured using the Parental Involvement in Academic Functioning Scale (Smojver-Ažić, Martinac Dorčić, \& Čar Bunčić, 2009), designed to measure specific aspects of parental involvement, warmth and support of autonomy during the college years. The theoretical basis of this questionnaire is the self-determination theory (Grolnick et al., 1997). It has 37 items rated on a scale from (1) not true for me to (7) true for me. Factor analysis showed that this scale has two subscales: (a) perception of parental support: perception of parental involvement and interest in the student's academic functioning; the experience of the students regarding the extent to which parents devote them their time and emotional and cognitive resources (e.g. Whenever I need support, I can count on her; She understands my decisions and choice) and (b) perception of parental control: the perception of intrusion and complaints from parents (e.g. She complains when I do not take exams regularly). The first subscale has 22 items, and the second has 13 items. Two items were excluded due to unsatisfactory factor loadings and one was reverse coded. Both scales had good reliability: Cronbach alpha for perception of support was .91 and for perception of control .86 (Smojver-Ažić et al., 2009). Good reliability was confirmed on the current sample ( $\alpha=.94$ for perception of support and $\alpha=.88$ for perception of control). Students assessed the behavior of the more involved parent, which in this sample was most often the mother (77\%). A higher score indicates a higher perception of support and control. A moderate negative correlation was found between the perception of support and the perception of control, $r=$ $-.44, p<.01$.

Adaptation to college. Adaptation to college was assessed using The Student Adaptation to College Questionnaire (SACQ) (Baker \& Siryk, 1999). It is a 67item self-report questionnaire originally consisting of four subscales (academic adjustment, social adjustment, emotional adjustment and institutional attachment). Items are rated on a 9-point Likert scale from (0) does not apply to me to (8) fully applies to me. Consistent with a previous adaptation for a Croatian sample (Živčić-Bećirević, Smojver-Ažić, Kukić, \& Jasprica, 2007), three subscales with good reliability were used in the present research: academic adjustment (21 items; $\alpha=.90)$, social adjustment (13 items; $\alpha=.83$ ) and emotional adjustment (25 items; $\alpha=.91)$. The Academic Adjustment subscale measures a student's success at coping with the various educational demands characteristic of the college experience. The Social Adjustment subscale contains items relevant to the interpersonal-societal demands of college (e.g., forming friendships, joining groups, etc.). The Personal-Emotional subscale is designed to examine how a student is feeling psychologically and physically. The questionnaire was administered two times (during the first and during the third year of study). Higher scores indicate better adjustment.

\section{Procedure}

This study is a part of a larger longitudinal study of risk and protective factors of student adjustment to college, which was conducted in three phases: during the first (T1), second (T2) and third year of college (T3). At the end of the first semester (the first year of study), students completed questionnaires related to their attachment for mothers and fathers separately, adaptation to college and demographic data (gender and residential status). Parental involvement in academic functioning was assessed in the second year of study. Students completed the student adaptation to college questionnaire once more at the end of the third year of study. The questionnaires were groupadministered in the first phase of the study. In the second and the third phase of the study the questionnaires were given or mailed to the students, and the students were asked to complete them and return them within seven days. In order to match data, students wrote their academic identification number on questionnaires while the name of the student was not written anywhere. Students were informed about the purpose and method of data collection and voluntarily participated in the study. They could at any moment opt out without any consequences.

\section{Results}

\section{Correlations between adjustment, attachment and parental involvement in academic functioning}

Correlations between different aspects of adjustment, attachment and parental involvement in academic functioning are shown in Table 1.

The correlations between the aspects of adjustment in the initial and final measurements were positive and moderately high. All three aspects of final adjustment were significantly associated with all of the analyzed variables, with the exception of gender and residential status, which are correlated only with emotional adjustment (gender has positive, and residential status negative correlation). The avoidance dimension of attachment is significantly negatively correlated with parental support in academic functioning and positively with parental control, while attachment anxiety has a significant, low positive correlation only with parental control.

The avoidance dimension of attachment was found to be approximately equally correlated with all three categories of adjustment (correlations ranged from -.25 to 
Table 1. Summary of inter-correlations, means and standard deviations for scores on the attachment dimensions, adjustment to college, parental support, and parental control

\begin{tabular}{|c|c|c|c|c|c|c|c|c|c|c|c|c|}
\hline $\begin{array}{l}\text { Time of } \\
\text { measure- } \\
\text { ment }\end{array}$ & Variables & $(2)$ & (3) & (4) & $(5)$ & $(6)$ & $(7)$ & $(8)$ & (9) & $(10)$ & $(11)$ & (12) \\
\hline & (1) gender & -.12 & $-.17^{*}$ & .05 & .11 & -.10 & -.13 & -.13 & .09 & $.17^{*}$ & .03 & .02 \\
\hline & (2) residential status & & .08 & .06 & $-.25^{* *}$ & -.09 & -.05 & $.17^{*}$ & -.08 & $-.18^{*}$ & .03 & .04 \\
\hline $\mathrm{T} 1$ & (3) anxiety att. & & & $.18^{*}$ & $-.48^{* *}$ & -.10 & $-.22^{* *}$ & -.10 & $.16^{*}$ & $-.42^{* *}$ & $-.19^{*}$ & $-.18^{*}$ \\
\hline $\mathrm{T} 1$ & (4) avoidance att. & & & & $-.31^{* *}$ & $-.25^{* *}$ & $-.34^{* *}$ & $-.47^{* *}$ & $.32^{* *}$ & $-.30^{* *}$ & $-.34^{* *}$ & $-.32^{* *}$ \\
\hline $\mathrm{T} 1$ & (5) emot. adjustment & & & & & $.41^{* *}$ & $.49^{* *}$ & .15 & $-.27^{* *}$ & $.59^{*}$ & $.28^{* *}$ & $.29^{* *}$ \\
\hline $\mathrm{T} 1$ & (6) social adjustment & & & & & & $.58^{* *}$ & $.20^{*}$ & -.02 & $.21^{* *}$ & $.39^{* *}$ & $.25^{* *}$ \\
\hline $\mathrm{T} 1$ & (7) acad. adjustment & & & & & & & $.30^{* *}$ & $-.17^{*}$ & $.27^{* *}$ & $.36^{* *}$ & $.45^{* *}$ \\
\hline $\mathrm{T} 2$ & (8) parental support & & & & & & & & $-.44^{* *}$ & $.20^{*}$ & $.42^{* *}$ & $.42^{* *}$ \\
\hline $\mathrm{T} 2$ & (9) parental control & & & & & & & & & $-.22^{* *}$ & $-.27^{* *}$ & $-.32^{* *}$ \\
\hline $\mathrm{T} 3$ & (10) emot. adjustment & & & & & & & & & & $.48^{* *}$ & $.52^{* *}$ \\
\hline $\mathrm{T} 3$ & (11) social adjustment & & & & & & & & & & & $.67^{* *}$ \\
\hline \multirow[t]{3}{*}{$\mathrm{T} 3$} & (12) acad. adjustment & & & & & & & & & & & 1 \\
\hline & $M$ & 1 & 4.06 & 5.95 & 131.88 & 64.68 & 130.32 & 5.59 & 3.00 & 132.33 & 69.85 & 126.83 \\
\hline & $S D$ & 1 & 1.51 & 2.16 & 30.71 & 15.01 & 23.24 & 0.94 & 1.08 & 33.09 & 13.96 & 24.07 \\
\hline
\end{tabular}

Notes: For all scales, higher scores are indicative of more extreme responding in the direction of the construct assessed. The coding of the nominal predictors was as follows: Gender (0-female, 1-male), Residential status (0-live with parents, 1-live away from parents). T1-first year; T2-second year; T3-third year. ${ }^{*} p<.05 ;{ }^{* *} p<.01$.

-.34 and were all significant), while the anxiety dimension has a prominent negative correlation with emotional adjustment $(r=-.48)$. Correlations between adjustment and parental involvement in academic functioning were generally higher when adjustment was measured during the third year of college.

\section{The predictive effects of attachment to parents and initial adjustment to college on perception of parental involvement in academic functioning}

To examine the predictive effects of attachment to parents and initial adjustment to college on students' perception of parental involvement in academic functioning, two hierarchical regression analyses were performed. Gender and residential status as demographic variables were used in the first step of the analysis, dimensions of attachment to parents were used in the second step of analysis, and initial adjustment to college was used in the third step of analysis (Table 2). The order of entering the variables into the model was based on the stability of each characteristic: demographics and more stable characteristics were entered earlier, while the contextual specific variable (the adjustment to college) was entered last.

The combination of all of the variables accounted for $29 \%$ of variability in parental support and $18 \%$ of variability in parental control (Table 2). The variables entered in the first step explained only $4 \%$ of variability in parental support: students who live away from parents perceived greater parental support; for the parental control dimension, residential status became a significant predictor in the final step (students who stay with parents experience more control). The dimensions of attachment to parents explained additional $23 \%$ of variance of parental support and $11 \%$ of variance of parental control in academic functioning. The avoidance dimension of attachment was a significant negative predictor of parental support and positive predictor of parental control. The predictors entered in the final step did not significantly improve the model fit in either regression analyses. However, lower emotional adjustment was found to be a significant predictor of parental control.

\section{Parental attachment and involvement as predictors of student adjustment during third year}

Separate analyses were performed for academic, emotional, and social adjustment. Predictor variables were entered in three steps; the order of entry was based on the stability of measured characteristics. After controlling for the demographic variables (gender and residential status), parental attachment as a more stable characteristic was entered. In the last step, the contribution of parental involvement in academic functioning (as a contextual specific proximal variable) was examined. The results of the hierarchical multiple regression analyses of the parental attachment and involvement for student adjustment measured in the third year are shown in Table 3.

Predictor variables together explained $23 \%$ of the variance in academic adjustment. Gender and residential status were not significant predictors of academic adjustment, while the dimensions of attachment together accounted for $10 \%$ of the variance. Although the avoidance 
Table 2. Results of the hierarchical regression analyses for predicting parental support and control

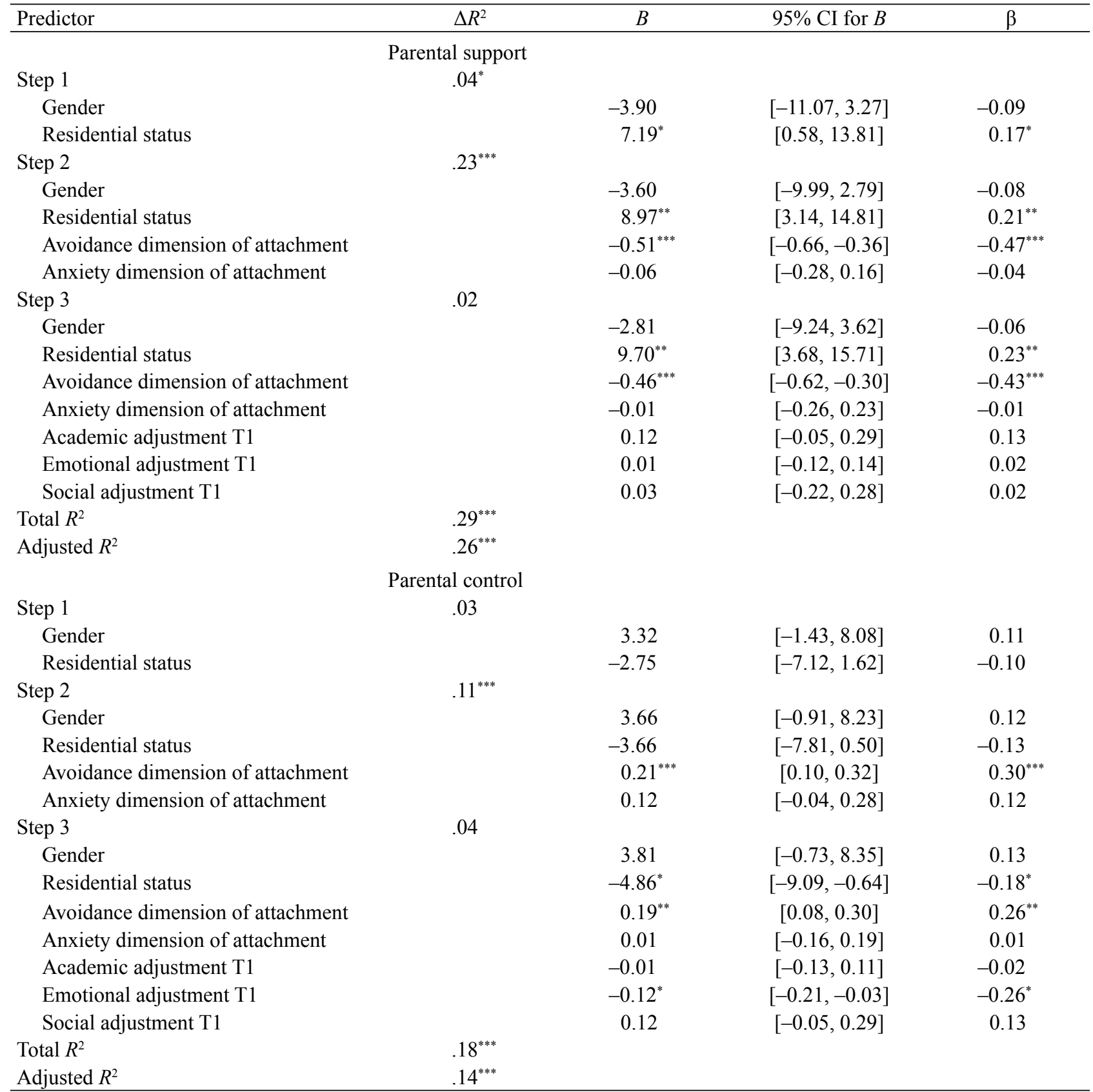

Notes: The coding of the nominal predictors was as follows: Gender ( 0 - female, 1 - male), Residential status ( 0 - live with parents, 1- live away from parents).

${ }^{*} p<.05 ;{ }^{* *} p<.01 ;{ }^{* * *} p<.001$

dimension was a significant predictor in the second step $(\beta$ $=-0.28, p<.01)$, after introducing the variables of parental involvement, it was no longer a significant predictor. In the final step, dimensions of parental involvement explained additional $13 \%$ of the variance, with parental support as a positive predictor. Students who had perceived more parental support experienced better academic adjustment after three years of study.

Demographic variables, parental attachment and dimensions of parental involvement in academic functioning significantly predicted emotional adjustment at T3 (28\%). Both variables included in the first step showed as significant for emotional adjustment, gender as a positive predictor and residential status as a negative predictor. After including dimensions of attachment in the second step, demographic variables were no longer significant but both dimensions of attachment were negative predictors of emotional adjustment. In the final step, in addition to gender and residential status, only anxiety attachment to parents stayed a significant negative predictor of emotional adjustment: female students, students who moved from home and students with higher anxiety dimensions experienced more emotional problems. Dimensions of parental involvement 
Table 3. The results of the hierarchical regression analyses for predicting academic, emotional and social adjustment in the third year of college

\begin{tabular}{|c|c|c|c|c|}
\hline Predictor & $\Delta R^{2}$ & $B$ & $95 \%$ CI for $B$ & $\beta$ \\
\hline & Academic adjustment & & & \\
\hline Step 1 & .00 & & & \\
\hline Gender & & 3.77 & {$[-4.67,12.21]$} & 0.07 \\
\hline Residential status & & 0.81 & {$[-6.99,8.61]$} & 0.02 \\
\hline Step 2 & $.10^{* * *}$ & & & \\
\hline Gender & & 3.22 & {$[-4.98,11.41]$} & 0.06 \\
\hline Residential status & & 2.40 & {$[-5.10,9.90]$} & 0.05 \\
\hline Avoidance dimension of attachment & & $-0.34^{* *}$ & {$[-0.54,-0.15]$} & $-0.28^{* *}$ \\
\hline Anxiety dimension of attachment & & -0.19 & {$[-0.47,0.09]$} & -0.11 \\
\hline Step 3 & $.13^{* * *}$ & & & \\
\hline Gender & & 5.70 & {$[-2.02,13.41]$} & 0.11 \\
\hline Residential status & & -1.92 & {$[-9.13,5.29]$} & -0.04 \\
\hline Avoidance dimension of attachment & & -0.09 & {$[-0.30,0.12]$} & -0.07 \\
\hline Anxiety dimension of attachment & & -0.14 & {$[-0.41,0.12]$} & -0.08 \\
\hline Parental support & & $0.39^{* * *}$ & {$[0.18,0.59]$} & $0.34^{* * *}$ \\
\hline Parental control & & -0.26 & {$[-0.54,0.03]$} & -0.15 \\
\hline Total $R^{2}$ & $.23^{* * *}$ & & & \\
\hline \multirow[t]{2}{*}{ Adjusted $R^{2}$} & $.20^{* * *}$ & & & \\
\hline & Emotional adjustment & & & \\
\hline Step 1 & $.06^{* *}$ & & & \\
\hline Gender & & $12.66^{*}$ & {$[1.39,23.92]$} & $0.18^{*}$ \\
\hline Residential status & & $-10.70^{*}$ & {$[-21.11,-0.30]$} & $-0.16^{*}$ \\
\hline Step 2 & $.19^{* * *}$ & & & \\
\hline Gender & & 9.05 & {$[-1.23,19.33]$} & 0.13 \\
\hline Residential status & & -7.88 & {$[-17.29,1.53]$} & -0.12 \\
\hline Avoidance dimension of attachment & & $-0.38^{* *}$ & {$[-0.62,-0.13]$} & $-0.22^{* *}$ \\
\hline Anxiety dimension of attachment & & $-0.84^{* * *}$ & {$[-1.19,-0.48]$} & $-0.34^{* * *}$ \\
\hline Step 3 & .03 & & & \\
\hline Gender & & $10.68^{*}$ & {$[0.40,20.96]$} & $0.15^{*}$ \\
\hline Residential status & & $-10.30^{*}$ & {$[-19.90,-0.70]$} & $-0.16^{*}$ \\
\hline Avoidance dimension of attachment & & -0.23 & {$[-0.51,0.04]$} & -0.14 \\
\hline Anxiety dimension of attachment & & $-0.80^{* * *}$ & {$[-1.16,-0.45]$} & $-0.33^{* * *}$ \\
\hline Parental support & & 0.18 & {$[-0.10,0.45]$} & 0.11 \\
\hline Parental control & & -0.25 & {$[-0.63,0.12]$} & -0.11 \\
\hline Total $R^{2}$ & $.28^{* * *}$ & & & \\
\hline \multirow[t]{2}{*}{ Adjusted $R^{2}$} & $.25^{* * *}$ & & & \\
\hline & Social adjustment & & & \\
\hline Step 1 & .01 & & & \\
\hline Gender & & 2.29 & {$[-2.61,7.20]$} & 0.08 \\
\hline Residential status & & 0.80 & {$[-3.73,5.32]$} & 0.03 \\
\hline Step 2 & $.12^{* * *}$ & & & \\
\hline Gender & & 1.99 & {$[-2.71,6.69]$} & 0.06 \\
\hline Residential status & & 1.81 & {$[-2.49,6.11]$} & 0.06 \\
\hline Avoidance dimension of attachment & & $-0.22^{* * *}$ & {$[-0.34,-0.11]$} & $-0.31^{* * *}$ \\
\hline Anxiety dimension of attachment & & -0.11 & {$[-0.27,0.05]$} & -0.11 \\
\hline Step 3 & $.09^{* * *}$ & & & \\
\hline Gender & & 3.16 & {$[-1.36,7.68]$} & 0.10 \\
\hline Residential status & & -0.34 & {$[-4.56,3.88]$} & -0.01 \\
\hline Avoidance dimension of attachment & & -0.10 & {$[-0.22,0.02]$} & -0.14 \\
\hline Anxiety dimension of attachment & & -0.09 & {$[-0.24,0.07]$} & -0.09 \\
\hline Parental support & & $0.21^{* *}$ & {$[0.09,0.33]$} & $0.31^{* *}$ \\
\hline Parental control & & -0.10 & {$[-0.26,0.07]$} & -0.10 \\
\hline Total $R^{2}$ & $.22^{* * *}$ & & & \\
\hline Adjusted $R^{2}$ & $.19^{* * *}$ & & & \\
\hline
\end{tabular}

Notes: The coding of the nominal predictors was as follows: Gender ( 0 - female, 1 - male), Residential status $(0$ - live with parents, 1 - live away from parents).

${ }^{*} p<.05 ;{ }^{* *} p<.01 ;{ }^{* * *} p<.001$ 
in academic functioning were not important to emotional adjustment during the third year of college.

The combination of the predictor variables explained $22 \%$ of the variance in social adjustment at the third year of college. Although demographic variables were not significant predictors, the variables in the other two steps significantly contributed to the explained variance of social adjustment. Attachment to parents explained additional $12 \%$ of the variance in social adjustment (with the avoidance dimension of attachment as a significant predictor only in the second but not in the final step of analysis), while parental involvement explained further $9 \%$ of the variance. Parental support was a positive predictor of social adjustment at T3. The role of the avoidance dimension of attachment changed and was no longer significant when the parental involvement in academic functioning was included.

\section{Discussion}

The present findings, based on a longitudinal threeyear study, suggest that parental involvement in academic functioning in second college year is more related to the quality of attachment to parents than to the initial adjustment to college. This result is in accordance with the hypothesis related to our first research question, i.e. that perception of parental support and parental control would both be significantly predicted by attachment. Generally, initial college adjustment did not significantly predict the scores on dimensions of parental involvement although initial emotional adjustment emerged as a significant predictor for parental control.

According to our results, only the avoidance dimension significantly predicted the perception of parental support and control. Because our results indicated the importance of attachment for parental involvement in academic functioning, it could be expected that positive past relationships and secure attachment would be a precondition for recognizing new developmental needs during emerging adulthood. Previous research confirmed that parental responsiveness was positively related to secure attachment and negatively related to avoidance in middle childhood (e.g. Kerns, Tomich, Aspelmeier, \& Contreras, 2000). Similarly, adolescents with secure working models were found to perceive their families as highly supportive (Kobak \& Sceery, 1988). Secure attachment relationships in times of stress allow students to adjust to new environments with confidence in their parent's availability, respecting their needs for competence and autonomy (Kenny, 1987).

Our results show that students who left home perceived more support from their parents but those who remained at home experienced more control. According to Mattanah et al. (2011) links between attachment and adjustment were stronger for student residing away from their parents when compared with students living at home during college. For students who remained at home, usually little has changed: They remain under the direct daily supervision of their parents and have less opportunity to practice independence, and their parents often do not recognize that they have matured. This may be a reason why these students experience their parents as more controlling, especially if they have emotional problems. In contrast, those who left home experience many changes with new responsibilities for their daily functions, which lead to an increased need for and receipt of parental support. Importantly, parents also need to adjust to new circumstances during their child's transition to college and realize that their children have become more independent in some ways, yet still need them.

The second and main question of our study concerned the effects of student perception of parental involvement on their adjustment across academic, emotional, and social domains. According to the presumption that various aspects of the parent-student relationship may be relevant, it is interesting to discover which aspects are important in predicting different adjustment outcomes after three years of college, after accounting for student's gender and residential status. It is worth noting that students from the current sample were, in general, well-adjusted at the beginning and during the third year of college regarding academic, social and emotional functioning.

Our results show that academic adjustment after three years of study is affected by higher parental support. Previous research found evidence that higher parental involvement contributes to an increase in a child's perceived level of competence, autonomous self-regulation, and school achievement (Grolnick, Ryan, \& Deci, 1991; Spera, 2005). In the present study, parental support and control are moderately dependent dimensions. According to our operationalization of parental involvement, parents who are supportive openly discuss study related problems, provide conditions needed for learning, show understanding before exams, care about students' feelings, and demonstrate confidence in students' abilities. Parents who are controlling worry too much about college issues, pressure students to learn, complain about failure or the lack of fulfilling obligations, have high expectations, and treat the students as children. This type of control undermines the student's autonomy and competence. According to the results of this study, better academic adjustment is related to supportive parenting. Although parental control did not emerge as a single predictor of academic adjustment, significant moderate correlation with this criterion implies the importance of recognizing student's need for autonomy in fulfilling academic obligations.

The results of this study show that female students, students who moved from home, and students with a higher anxiety dimension of attachment to parents have poorer emotional adjustment after the three years of college. Schultheiss and Blusistein (1994) also found that attachment to parents was associated with positive adjustment to college for women but not for men, while according to a meta-analytic review (Mattanah et al., 
2011) neither the parent's gender nor the student's gender moderate the attachment-adjustment relationship. A number of studies have found that having a positive attachment relationship with parents can assist students in transitioning to college, as can a healthy separationindividuation process (e.g., Lapsley et al., 1990; Mattanah et al., 2004; Rice, 1992; Wintre \& Yaffe, 2000).

Our results revealed that social adjustment during the third year of college is an outcome of parental support too. Good relationships with parents provide a foundation for good social relationships in college. It is possible that supportive parenting promotes the development of positive expectations regarding the self and others, which in turn facilitates positive interactions with the social environment.

Considering all of the above, what is important for student adjustment during the first three college years? Our data suggest diverse effects of the dimensions of attachment and parental involvement on different aspects of college student adjustment. The findings from the current study correspond with previous studies suggesting a small to medium size of relationships between the indicators of parental attachment quality and adjustment outcomes (Mattanah et al., 2011).

While attachment was a significant predictor of only emotional adjustment, it was parental support in academic functioning that predicted the academic and social adjustment. It is interesting that the anxiety dimension of attachment is the single significant predictor of emotional adjustment in the final step, while for academic and social adjustment the effects of the avoidance dimension were overshadowed by that of parental support. One of the possible reasons for this effect is that parental support is more related to the avoidance dimension. Higher avoidance reflects interpersonal distance as a result of the perception of parents as rejecting, cold and unengaged. Students with low avoidance are more prone to perceive their parents as more supportive. A combination of the positive expectations of parents due to previous experiences and the present support of academic functioning contribute to students' academic and social adjustment. The reason why parental involvement in academic functioning is related to these two aspects of adjustment and not with emotional adjustment may be explained by the nature of the measures. Parental support is related to students' college experiences expressed as academic and social adjustment, while emotional adjustment represents a general psychological outcome that is possibly more related to attachment. This is in accordance with the conclusions of Soenens and Vansteenkiste (2005) concerning the importance of respecting the domain-specific nature of certain parenting behaviors when explaining specific outcomes. The results of the current study on academic adjustment partially support the findings of Klein and Pierce (2009), in which students whose parents provided the unique combination of high care and low overprotection, had better adjustment across several domains of collegerelated issues. Our findings on the predictors of emotional adjustment are more in line with studies that confirmed that the internalization of problems in adolescence (anxiety, depression, somatic complaints without known medical cause) are related either to insecure attachment or to parental control (Vivona, 2000; Wood, McLeod, Sigman, Hwang, \& Chu, 2003). The anxiety dimension of attachment is associated with dependence on others' confirmation and it reflects the degree of the fear of rejection and dependence on others for approval and self-worth. This could explain why students with higher anxiety have more emotional problems (Bartholomew \& Horowitz, 1991). According to Bernier et al. (2004), preoccupation with attachment accentuates the negative correlation between parental psychological control and social adjustment, while dismissive attachment tendencies were found to be unrelated to adjustment to college.

The present findings underline the importance of parental support for students' adjustment to college. Parenting behaviors that are believed to be sensitive to developmental needs during adolescence include warm and responsive involvement, encouragement towards psychological autonomy and demand for age appropriate behavior, limit setting and monitoring (Karavasilis et al., 2003). Parenting in late adolescence and emerging adulthood may require encouraging the young person's increasing independence and autonomy, while still providing guidance and support. This may be even more important for new generations of students whose parents have been very involved in their day-to-day activities during their childhood and adolescent years (Howe \& Strauss, 2007). During college, involved parents demonstrate interest in their child's college experience, become more informed about the institution, and know when and how to appropriately provide encouragement and guidance to their children. Some findings (Agliata \& Renk, 2008; Wintre \& Yafee, 2000) have led to the conclusion that parents should be educated on how to facilitate their child's transition to college. According to these authors, the effects of parents on students' university adjustment were related to the perception of reciprocity with parents and the specific content of communications surrounding college related issues, which led to direct effects on adjustment to college (Agliata \& Renk, 2008). The advice to parents, 30-40 years ago, was to allow their teenagers the freedom to develop into adults. According to the findings from the current study as well as others (e.g. Sax \& Wartman, 2010), both autonomy and attachment in relation to parents are markers of healthy student development.

There are several limitations to this study. The study relied exclusively on students' self-reports. Parental involvement was measured through student perception and not through observations of actual support and control. In addition, our results are correlational; therefore, the direction of causality cannot be determined. Furthermore, our sample represents predominantly female, relatively well-adjusted students: almost three quarters of them finished their undergraduate study on time, which may limit the generalizability of the findings. 
A unique aspect of this research is related to the specific college experience in Croatia where a substantial number of students remain at home during their college years. Besides that, the supportive family setting is common to the emerging adults in Southern European countries (Zupančič et al., 2014) which suggests that our study results should be further tested in different cultures. A further limitation is related to the measure of parental involvement that reveals student's perception referred to the more involved parent, who was, according to their reports, usually the mother. In future studies, it would be interesting to analyze the specific contributions of mothers and fathers with respect to the gender of the student.

One of the main strength of this study is its longitudinal design. It was focused on the process of adjustment to college and examined how it progressed over time across a different range of outcomes. Also, data on attachment to parents, parental involvement and adjustment to college were collected at different time points which significantly reduces the problem of common method variance. A scale of parental involvement in academic functioning, as a specific measure of parenting related to academic experiences, has shown its usefulness in explaining different adjustment domains. The role of attachment to parents was confirmed using a dimensional approach with self-report measure that is not common in analyzing adjustment to college.

\section{Conclusion}

This longitudinal study explored the predictive effects of both parental attachment as a distal determinant and parental involvement as a proximal determinant on college students' adjustment. According to the results, it is important to acknowledge different theoretical concepts and their possible complementary contribution. We can conclude that various factors related to parenting continue to play important roles in college students' adjustment, with different effects depending upon the developmental domain.

\section{References}

Agliata, A. K., \& Renk, K. (2008). College students' adjustment: The role of parent-college student expectation discrepancies and communication reciprocity. Journal of Youth and Adolescence, 37(8), 967-982.

Allen, J. P., Hauser, S. T., Bell, K. L., \& O’Connor, T. G. (1994). Longitudinal assessment of autonomy and relatedness in adolescent-family interactions as predictors of adolescent ego development and selfesteem. Child development, 65(1), 179-194.

Arnett, J. J. (2004). Emerging adulthood: The winding road from the late teens through the twenties. New York, NY, USA: Oxford University Press.
Baker, R. W. \& Siryk, B. (1984). Measuring academic motivation of matriculating college freshmen. Journal of College Student Personnel, 25, 459-464.

Baker, R. W. \& Siryk, B. (1999). Student Adaptation to College Questionnaire: Manual. Los Angeles, CA, USA: Western Psychological Services.

Bartholomew, K., \& Horowitz, L. M. (1991). Attachment styles among young adults: A test of a four-category model. Journal of Personality and Social Psychology, 61(2), 226-244.

Bernier, A., Larose, S., Boivin, M., \& Soucy, N. (2004). Attachment state of mind: Implications for adjustment to college. Journal of Adolescent Research, 19(6), 783-806.

Brennan, K. A., Clark, C. L., \& Shaver, P. R. (1998). Self-report measurement of adult attachment: An integrative overview. In J. A. Simpson \& V. S. Rholes (Eds.), Attachment theory and close relationships (pp. 46-76). New York, NY, USA: Guilford Press.

Chickering, A. W., \& Reisser, L. (1993). Education and identity: The Jossey-Bass Higher and Adult Education Series. San Francisco, CA, USA: Jossey-Bass.

Crede, M., \& Niehorster, S. (2012). Adjustment to college as measured by the Student Adaptation to College Questionnaire: A quantitative review of its structure and relationships with correlates and consequences. Educational Psychology Review, 24, 133-165.

Fan, X., \& Chen, M. (2001). Parental involvement and students' academic achievement: A meta-analysis. Educational psychology review, 13(1), 1-22.

Farnell, T., Doolan, K., Matković, T., \& Cvitan, M. (2011). Socijalna $i$ ekonomska slika studentskog života u Hrvatskoj: Nacionalno izvješće istraživanja Eurostudent za Hrvatsku [Social and economic picture of student life in Croatia: A national report of the Eurostudent research in Croatia]. Zagreb, Croatia: Institute for the Development of Education.

Gerdes, H., \& Mallinckrodt, B. (1994). Emotional, social, and academic adjustment of college students: A longitudinal study of retention. Journal of Counseling \& Development, 72(3), 281-288.

Grolnick, W. S., Deci, E. L., \& Ryan, R. M. (1997). Internalization within the family: The selfdetermination theory perspective. In J. E. Grusec \& L. Kuczynski (Eds), Parenting and children's internalization of values: A handbook of contemporary theory (pp. 135-161). New York, NY, USA: Wiley.

Grolnick, W. S., \& Ryan, R. M. (1989). Parent styles associated with children's self-regulation and competence in school. Journal of Educational Psychology, 81(2), 143-154.

Grolnick, W. S., Ryan, R. M., \& Deci, E. L. (1991). Inner resources for school achievement: Motivational mediators of children's perceptions of their parents. Journal of Educational Psychology, 83(4), 508-517.

Hanak, N., \& Dimitrijevic, A. (2013). A Serbian version of modified and revised Experiences in Close Relationships Scale (SM-ECR-R). Journal of Personality Assessment, 95(5), 530-538. 
Hill, N. E., \& Tyson, D. F. (2009). Parental involvement in middle school: A meta-analytic assessment of the strategies that promote achievement. Developmental Psychology, 45(3), 740-763.

Howe, N., \& Strauss, W. (2007). Millennials go to college. Great Falls, VA, USA: LifeCourse Associates.

Kamenov, Ž., \& Jelić, M. (2003). Validacija instrumenta za mjerenje privrženosti u različitim vrstama bliskih odnosa: Modifikacija Brennanova Inventara iskustava $\mathrm{u}$ bliskim vezama. [Validation of adult attachment measure in various types of close relationships: Modification of Brennan's Experiences in close relationship inventory]. Suvremena psihologija, 6(1), 73-91.

Kamenov, Ž., \& Jelić, M. (2005). Stability of attachment styles across students' romantic relationships, friendships and family relations. Review of Psychology, 12, 115-123.

Karavasilis, L., Doyle, A. B., \& Markiewicz, D. (2003). Associations between parenting style and attachment to mother in middle childhood and adolescence. International Journal of Behavioral Development, 27(2), 153-164.

Kenny, M. E. (1987). The extent and function of parental attachment among first-year college students. Journal of Youth and Adolescence, 16(1), 17-29.

Kerns, K. A., Tomich, P. L., Aspelmeier, J. E., \& Contreras, J. M. (2000). Attachment-based assessments of parent-child relationships in middle childhood. Developmental Psychology, 36(5), 614-626.

Klein, M.B., \& Pierce, J.D. (2009). Parental care aids, but parental overprotection hinders college adjustment. Journal of College Student Retention: Research, Theory and Practice, 11, 167-181

Kobak, R. R., \& Sceery, A. (1988). Attachment in late adolescence: Working models, affect regulation, and representations of self and others. Child Development, 59, 135-146.

Lapsley, D. K., Rice, K. G., \& FitzGerald, D. P. (1990). Adolescent attachment, identity, and adjustment to college: Implications for the continuity of adaptation hypothesis. Journal of Counseling \& Development, 68(5), 561-565.

Mattanah, J. F., Hancock, G. R., \& Brand, B. L. (2004). Parental attachment, separation-individuation, and college student adjustment: A structural equation analysis of mediational effects. Journal of Counseling Psychology, 51(2), 213-225.

Mattanah, J. F., Lopez, F. G., \& Govern, J. M. (2011). The contributions of parental attachment bonds to college student development and adjustment: A metaanalytic review. Journal of Counseling Psychology, 58(4), 565-596.

Nelson, L. J., Padilla-Walker, L. M., Christensen, K. J., Evans, C. A., \& Carroll, J. S. (2011). Parenting in emerging adulthood: An examination of parenting clusters and correlates. Journal of Youth and Adolescence, 40(6), 730-743.
Ratelle, C. F., Larose, S., Guay, F., \& Senécal, C. (2005). Perceptions of parental involvement and support as predictors of college students' persistence in a science curriculum. Journal of Family Psychology, 19(2), 286-293.

Rice, K.G. (1992). Separation-individuation and adjustment to college: A longitudinal study. Journal of Counseling Psychology, 39, 203-213.

Rice, K. G., FitzGerald, D. P., Whaley, T. J., \& Gibbs, C. L. (1995). Cross-sectional and longitudinal examination of attachment, separation-individuation, and college student adjustment. Journal of Counseling \& Development, 73(4), 463-474.

Ryan, R. M., \& Deci, E. L. (2000). Self-determination theory and the facilitation of intrinsic motivation, social development, and well-being. American Psychologist, 55(1), 68.

Sax, L. J., \& Wartman, K. L. (2010) Studying the impact of parental involvement on college student development: A review and agenda for research. In J. C. Smart (Ed.), Higher education: Handbook of theory and research (Vol. 25, pp. 219-255). London, UK: Springer.

Schultheiss, D. E. P., \& Blustein, D. L. (1994). Role of adolescent-parent relationships in college student development and adjustment. Journal of Counseling Psychology, 41(2), 248-255.

Smojver-Ažić, S., Martinac Dorčić, T., \& Čar Bunčić, M. (2009, July). Role of perceived parental involvement and control in university student adjustment. Poster session presented at 30th Stress and Anxiety Research Society Conference, Budapest.

Soenens, B., \& Vansteenkiste, M. (2005). Antecedents and outcomes of self-determination in 3 life domains: The role of parents' and teachers' autonomy support. Journal of Youth and Adolescence, 34, 589-604.

Soucy, N., \& Larose, S. (2000). Attachment and control in family and mentoring contexts as determinants of adolescent adjustment at college. Journal of Family Psychology, 14(1), 125-143.

Spera, C. (2005). A review of the relationship among parenting practices, parenting styles, and adolescent school achievement. Educational Psychology Review, 17(2), 125-146.

Taub, D. J. (2008). Exploring the impact of parental involvement on student development. New Directions for Student Services, 122, 15-28.

Vivona, J. M. (2000). Parental attachment styles of late adolescents: Qualities of attachment relationships and consequences for adjustment. Journal of Counseling Psychology, 47, 316-329.

Wartman, K.L., \& Savage, M.(2008). Parental involvement in higher education: understanding the relationship among students, parents, and the institution. ASHE Higher Education Report, 33(6), 1-125.

Wei, M., Russell, D. W., Mallinckrodt, B., \& Vogel, D. L. (2007). The Experiences in Close Relationship Scale (ECR)-short form: Reliability, validity, and factor structure. Journal of Personality Assessment, 88(2), 187-204. 
Wei, M., Russell, D. W., \& Zakalik, R. A. (2005). Adult attachment, social self-efficacy, self-disclosure, loneliness, and subsequent depression for freshman college students: A longitudinal study. Journal of Counseling Psychology, 52(4), 602-614.

Wintre, M. G. \& Yaffe, M. (2000). First-year students' adjustment to university life as a function of relationships with parents. Journal of Adolescent Research, 15(1), 9-37.

Wood, J. J., McLeod, B. D., Sigman, M., Hwang, W. C., \& Chu, B. C. (2003). Parenting and childhood anxiety: Theory, empirical findings, and future directions. Journal of Child Psychology and Psychiatry, 44, 134-151.

Zupančič, M., Komidar, L., \& Puklek Levpušček, M. (2014). Individuation in Slovene emerging adults: Its associations with demographics, transitional markers, achieved criteria for adulthood, and life satisfaction. Journal of adolescence, 37(8), 14211433. doi: 10.1016/j.adolescence.2014.03.014

Živčić-Bećirević, I., Smojver-Ažić, S., Kukić, M., \& Jasprica, S. (2007). Akademska, socijalna i emocionalna prilagodba na studij s obzirom na spol, godinu studija i promjenu mjesta boravka [Age and gender differences in academic, social and emotional college adjustment]. Psihologijske teme, 1(16), 121-141. 